\title{
Quality of royal jelly produced by Africanized honeybees fed a supplemented diet
}

\author{
Maria Josiane SEREIA ${ }^{1}$, Vagner de Alencar Arnaut de TOLEDO ${ }^{2 *}$
}

\begin{abstract}
This study was carried out to evaluate the effect of artificial supplements prepared with soybean protein isolate, brewer's yeast, mixture of soybean protein isolate with brewer's yeast, linseed oil, palm oil, and a mixture of linseed oil with palm oil on the physicochemical and microbiological composition of royal jelly produced by Africanized honey bee colonies. Considering these results, providing supplements for Africanized honeybee colonies subjected to royal jelly production can help and strengthen the technological development of the Brazilian beekeeping industry increasing its consumption in the national market. This research presents values of royal jelly a little different from those established by the Brazilian legislation. This fact shows that is important to discuss or change the official method for royal jelly analysis. The characterization of physicochemical and microbiological parameters is important in order to standardize fresh, frozen, and lyophilized royal jelly produced by Africanized honeybees.
\end{abstract}

Keywords: microbiological analysis; physicochemical composition; supplementation.

\section{Introduction}

In 1912, the German scientist J. Langer showed conclusively that royal jelly is the secretion of a highly specialized set of hypo pharyngeal and mandibular glands located in the head of worker bees aged between 5 and 15 days (WILLSON, 1955; LERCKER et al., 1993). This fluid is homogeneous, creamy, milky white coloured, with a slightly acid flavour and a strong and pungent odour (LERCKER et al., 1993).

Royal jelly has a complex composition of proteins, amino acids, organic acids, sterols, phenols, sugars, minerals, and other unknown substances (VIUDA-MARTOS et al., 2008). One of the most important products for the colony is the royal jelly that is used to feed the worker larvae until the third day, drone larvae until pupation, and the queen throughout larval and adult stages (HAYDAK, 1970; WINSTON 1987). Under normal conditions, the amount of royal jelly produced by a colony depends on the number of larvae since royal jelly is not stored in the combs (HAYDAK, 1970).

Due to the high content of protein present in royal jelly, honeybees need a diet rich in sugars, vitamins, fatty acids, minerals, and all essential amino acids, which are mainly obtained from pollen consumption with the possible addition of a small amount of honey (WINSTON, 1987; SCHMIDT; BUCHMANN, 1992; LERCKER et al., 1993).

Different from the honey that honeybees produce from nectar of the flowers or other sugary substances, royal jelly is a product solely of glandular secretion; therefore, artificial supplementation may not affect its physicochemical composition keeping the final characteristics of the products intact (HAYDAK, 1960). Thus, it is possible that there is no restriction on the artificial supplementation of the colonies, in contrast with honey production.
Since Brazilian and international beekeeping products are increasingly in demand, special care is necessary in use of artificial supplementation to ensure that it does not change the composition of the final product thus ensuring the health of both honeybees and customers (BRASIL, 2007).

The pollen is stored in a hive but is not in large amounts like honey (WINSTON, 1987). Therefore, the commercial royal jelly production is not possible without artificial protein supplementation of the colonies.

Therefore, the physicochemical and microbiological parameters of royal jelly samples were analyzed. The samples were collected from Africanized honeybee colonies supplemented with artificial supplements prepared with different sources of oils and proteins to evaluate the association between the quality of royal jelly produced and the supplements provided and therefore compare them with the standards established by the Brazilian legislation (BRASIL, 2001).

\section{Materials and methods}

The microbiological and physicochemical analysis was performed at the Laboratory of food evaluation at the "Universidade Tecnológica Federal do Paraná, Campus de Campo Mourão".

Royal jelly samples - royal jelly samples were produced by Africanized honeybee colonies. Two experimental assays were carried out to evaluate a supplement made with different sources of oil and protein. Twenty colonies were randomly divided into four groups with five repetitions in each assay including the control.

In assay I, two sources of oil were evaluated in a standard supplement. In the first treatment, a mixture of linseed oil and

Received 5/9/2011

Accepted 18/2/2013 (005456)

${ }_{1}$ Coordenação de Engenharia e Tecnologia de Alimentos, Universidade Tecnológica Federal do Paraná - UTFPR, BR 369, Km 05, CP 271, CEP 87301-006, Campo Mourão, PR, Brazil

2 Departamento de Zootecnia, Universidade Estadual de Maringá - UEM, Av. Colombo, 5790, CEP 87020-900, Maringá, PR, Brazil, e-mail: abelha.vagner@gmail.com

${ }^{*}$ Corresponding author 
palm oil, brewer's yeast, soy protein isolate, honey, sugar, pollen, brown sugar, soy lecithin, vitamin complex, ascorbic acid, glutamic acid, and vanilla natural flavour (SLiPa) was prepared. In the second treatment, a mixture of linseed oil and palm oil was replaced with linseed oil (SLi), and in the third treatment, it was replaced with palm oil (SPA); the fourth treatment was the control (C I), i.e., the colonies were not fed a supplement (Table 1).

In assay II, two sources of protein were evaluated in a supplement. In the first treatment a mixture of soy protein isolate, brewer's yeast, linseed oil and palm oil, honey, sugar, pollen, brown sugar, soy lecithin, vitamin complex, ascorbic acid, glutamic acid, and vanilla natural flavouring (SPiLc) was prepared. In the second treatment, the mixture of soy protein isolate and brewer's yeast was replaced with soy protein isolate (SPi), and in the third treatment, it was replaced with brewer's yeast (SLc); the fourth treatment was the control (C II), i.e., the colonies were not supplemented (Table 1).

In both experimental assays, the Africanized honeybee colonies produced royal jelly with grafted larvae from a cell into acrylic cups using the Doolittle's modified method (DOOLITTLE, 1899) for 15 consecutive times. Seventy-five grams of fresh supplement were placed inside the rearing hive, except for the control. In each grafting, regardless the treatment, all the artificially-reared hive systems were supplemented with $900 \mathrm{~mL}$ sugar syrup (1:1).

The royal jelly was stored in labeled vials protected from light at $-20^{\circ} \mathrm{C}$ for three months, when it was analyzed. An average sample of each treatment was prepared by homogenization of 15 partial samples.

\subsection{Assessment of microbiological quality of royal jelly samples}

The royal jelly samples were evaluated for the presence of coliforms at $35^{\circ} \mathrm{C}$ and $45^{\circ} \mathrm{C}\left(\mathrm{MPN} . \mathrm{g}^{-1}\right)$; enumeration of moulds and yeasts $\left(\mathrm{CFU} . \mathrm{g}^{-1}\right)$, and Salmonella spp. These procedures followed the international rules listed in the Compendium of Methods for the Microbiological Examination of Foods (AMERICAN..., 1992), complying with Normative Instruction
No. 3, of January 19, 2001 from the Ministry of Agriculture, Livestock and Supply - MAPA (BRASIL, 2001).

An aliquot of $25 \mathrm{~g}$ (fresh weight) of royal jelly suspended in $225 \mathrm{~mL}$ of $0.1 \%$ buffered peptone water was made to estimate the Most Probable Number (MPN) of coliforms at $35^{\circ} \mathrm{C}$ and $45{ }^{\circ} \mathrm{C}$. Preparations of subsequent decimal dilutions were performed in tubes containing $9 \mathrm{~mL}$ of the same diluents until it was $1 / 1000$. Three repetitions from each dilution step were inoculated with an aliquot of $1 \mathrm{~mL}$ in three tubes containing $10 \mathrm{~mL}$ Lauryl Sulphate Triptose Broth (LST Broth) incubated in a bacteriological incubator at $35-37^{\circ} \mathrm{C}$ for 48 hours. After incubation, the broth in Duran tubes was observed for the presence or absence of gas inside.

For each decimal dilution, $1 \mathrm{~mL}$ in duplicate was incorporated into Potato Dextrose Agar (PDA) acidified with tartaric acid $10 \%$ until a $\mathrm{pH}$ of 3.5 was reached and incubated in a bacteriological incubator at $25^{\circ} \mathrm{C}$ for five days for moulds and yeasts counting.

Salmonella test was performed with $25 \mathrm{~g}$ of royal jelly samples added to $225 \mathrm{~mL}$ of Lactose Broth, with incubation at $35^{\circ} \mathrm{C}$. After 24 hours of incubation, $1 \mathrm{~mL}$ was transferred to $10 \mathrm{~mL}$ of tetrathionate and selenite cystine enrichment broth, which were incubated in a bacterial culture for 24 hours at $42{ }^{\circ} \mathrm{C}$ and $35^{\circ} \mathrm{C}$, respectively. After that, grooves were made using a nickel-chrome handle on Bismuth Sulphite Agar (BSA), Brilliant Green Agar (BGA), and Salmonella-Shigella Agar (SS) selective media, whose plates were incubated at $35^{\circ} \mathrm{C} / 24$ to 48 hours. When at least five typical colonies were found, they were transferred from the plates to grow in tubes of TripleSugar-Iron Agar (TSIA), which, in turn, were incubated at $35^{\circ} \mathrm{C}$ for 24 hours.

\subsection{Analysis methods for assessing the physicochemical quality of royal jelly}

The physicochemical parameters analysed were: $\mathrm{pH}$, acidity (mEq. $\left.\mathrm{kg}^{-1}\right)$, moisture (\%), sucrose and reducing sugars (\%), protein (\%), ash (\%), and lipids (\%). The analysis met the quality criteria standards and reference methods established by Normative Instruction No. 3 from January 19, 2001 MAPA (BRASIL, 2001).

Table 1. Quantity of ingredients in 100g of linseed oil and palm oil supplement (SLiPa), linseed oil supplement (SLi), palm oil supplement (SPa), soy protein isolate, brewer's yeast supplement (SPiLc), soy protein isolate supplement (SPi), yeast supplement (SLc), and control samples (C I and C II), supplied to Africanized honeybees colonies producing royal jelly.

\begin{tabular}{|c|c|c|c|c|c|c|c|c|c|}
\hline \multicolumn{10}{|c|}{ Ingredients (g/100 g) - Assay I } \\
\hline \multirow{2}{*}{ Treatments } & \multirow{2}{*}{$\begin{array}{l}\text { Soy protein } \\
\text { Isolate }\end{array}$} & \multicolumn{2}{|c|}{ Oils (g) } & \multirow{2}{*}{$\begin{array}{c}\text { brewer's } \\
\text { yeast }\end{array}$} & \multirow{2}{*}{ Sugar } & \multirow{2}{*}{ Honey } & \multirow{2}{*}{ Pollen } & \multirow{2}{*}{$\begin{array}{l}\text { Soybean } \\
\text { Lecithin }\end{array}$} & \multirow{2}{*}{$\begin{array}{l}\text { vitamin } \\
\text { nucleus }\end{array}$} \\
\hline & & Linseed & Palm & & & & & & \\
\hline $\mathrm{SLiPa}$ & 17.5 & 4.0 & 4.0 & 17.5 & 40.9 & 10.0 & 5.0 & 1.0 & 0.1 \\
\hline $\mathrm{SLi}$ & 17.5 & 8.0 & - & 17.5 & 40.9 & 10.0 & 5.0 & 1.0 & 0.1 \\
\hline $\mathrm{SPa}$ & 17.5 & - & 8.0 & 17.5 & 40.9 & 10.0 & 5.0 & 1.0 & 0.1 \\
\hline Control I & - & - & - & - & 50.0 & - & - & - & - \\
\hline \multicolumn{10}{|c|}{ Assay II } \\
\hline SPiLc & 17.5 & 4.0 & 4.0 & 17.5 & 40.9 & 10.0 & 5.0 & 1.0 & 0.1 \\
\hline SPi & 35.0 & 4.0 & 4.0 & 0.0 & 40.9 & 10.0 & 5.0 & 1.0 & 0.1 \\
\hline SLc & - & 4.0 & 4.0 & 35.0 & 40.9 & 10.0 & 5.0 & 1.0 & 0.1 \\
\hline Control II & - & - & - & - & 50.0 & - & - & - & - \\
\hline
\end{tabular}


Taking into account the high content of fatty acids insoluble in water, $\mathrm{pH}$ determination was based on the hydrogen ion concentration in the royal jelly solution in amid methanol using a pH meter (HANDYLAB OX10), an analytical scale (GEHAKA $A G$ ), and a magnetic stirrer (EVLAB, 017-1), following the analytical standards of the Association of Official Analytical Chemists (ASSOCIATION..., 1984).

Acidity was determined using a $\mathrm{pH}$ meter (HANDYLAB OX10), an analytical scale (GEHAKA AG), and a magnetic stirrer (EVLAB 017-1) and was expressed in mEq. $\mathrm{kg}^{-1}$ (ASSOCIATION..., 1984).

Moisture was determined by the gravimetric method in an oven with air circulation at $70{ }^{\circ} \mathrm{C} \pm 2{ }^{\circ} \mathrm{C}$ (ASSOCIATION..., 1984).

Sucrose and reducing sugars was determined by the Somogy-Nelson (SOMOGY, 1945) method, in which the sugar solution, treated with chloride 2, 3, 5-triphenyl tetrazolium, develops colour because of its reaction with the reducing sugars that are quantified using a spectrophotometer and absorbance measured at $550 \mathrm{~nm}$.

The protein content of the royal jelly samples was determined by the Micro Kjeldahl nitrogen distillation method (TECNAL), following the AOAC rules (ASSOCIATION..., 1984).

Ash was determined by the sample calcination in a muffle furnace (GEHAKA), and quantification of lipids of the royal jelly samples was carried out using a Soxhlet extractor (ASSOCIATION..., 1984).

\subsection{Statistical analyses}

Statistical analyses were carried out using the software Statistical Analysis System (STATISTICAL..., 2007) in a completely randomized design. Variance analysis and the $\mathrm{F}$ test $(p<0.05)$ were used with three repetitions for each parameter to check for significant differences in the microbiological and physicochemical quality of the royal jelly samples produced in the supplemented and non-supplemented Africanized honeybee colonies.

\section{Results and discussion}

A total of 84 microbiological and 189 physicochemical samples were analyzed. Table 2 shows the most probable number of coliforms at $35^{\circ} \mathrm{C}$ and $45^{\circ} \mathrm{C}$, moulds and yeast, and Salmonella spp. in $25 \mathrm{~g}$ of the royal jelly samples. The results were compared with the standards established by the Brazilian legislation (BRASIL, 2001).

\subsection{Microbiological quality of royal jelly samples}

The analysis of variance (ANOVA) showed no significant difference in the microbiological quality of the royal jelly produced in supplemented and non-supplemented Africanized honeybee colonies, with no correlation between the microbial composition of the royal jelly samples and the supplements analyzed.

The absence of microorganisms in pure royal jelly is due to the presence of active principles with bacteriostatic and bactericidal properties, especially on the form of nonspoilage microorganisms. Blum, Novak and Taber (1959) and Krell (1996), respectively conducted studies demonstrating the inhibitory effects on fungi and the royal jelly beneficial antiviral in vitro effect. Another fact to consider is that Good Manufacturing Practices (GMP) were used for collecting the samples, no trace of plant material, fungus, bacteria, or nonhuman animal material that could pose risks contamination of the sample was found.

Royal jelly inhibitory activity against the Escherichia coli, Salmonella spp. (25 g), Proteus, Bacillus subtilis, and Staphylococcus aureus was reported by Lavie (1968) and Yatsunami and Echigo (1985). These authors attributed much of the royal jelly antibiotic effect to the composition of its ether-soluble lipid fraction, which has a high content of polar aromatic organic acid compounds and unsaturated compounds, especially the 10-hydroxy-2-decenoic (10-HDA) acid. Fontana et al. (2004) reported that the insoluble fraction in ether contains two peptides, called royalisin and jellein, with antimicrobial activity for gram-positive, gram-negative bacteria, fungi, and yeasts.

Table 2. Levels of microorganisms in royal jelly samples (25 $\mathrm{g}$ fresh product): Average values established by the Brazilian legislation for Most probable number of coliforms at $35^{\circ} \mathrm{C}$ and $45^{\circ} \mathrm{C}\left(\mathrm{MPN} \cdot \mathrm{g}^{-1}\right)$, moulds and yeast $\left(\mathrm{CFU} \cdot \mathrm{g}^{-1}\right)$, and Salmonella spp. $(25 \mathrm{~g})$.

\begin{tabular}{|c|c|c|c|c|}
\hline${ }^{\star}$ Variation source & $\begin{array}{c}\text { Coliforms at } 35^{\circ} \mathrm{C} \\
\left(\mathrm{MPN}^{-g^{-1}}\right)\end{array}$ & $\begin{array}{c}\text { Coliforms at } 45^{\circ} \mathrm{C} \\
\left(\mathrm{MPN} \cdot \mathrm{g}^{-1}\right)\end{array}$ & $\begin{array}{c}\text { Moulds and Yeasts } \\
\left(\text { CFU.g }{ }^{-1}\right)\end{array}$ & $\begin{array}{c}\text { Salmonella spp. } \\
(25 \mathrm{~g})\end{array}$ \\
\hline $\mathrm{SLiPa}$ & $<3$ & $<3$ & $<10^{1}$ & Absent \\
\hline $\mathrm{SLi}$ & $<3$ & $<3$ & $<10^{1}$ & Absent \\
\hline $\mathrm{SPa}$ & $<3$ & $<3$ & $<10^{1}$ & Absent \\
\hline SPiLc & $<3$ & $<3$ & $<10^{1}$ & Absent \\
\hline SPi & $<3$ & $<3$ & $<10^{1}$ & Absent \\
\hline SLc & $<3$ & $<3$ & $<10^{1}$ & Absent \\
\hline Control & $<3$ & $<3$ & $<10^{1}$ & Absent \\
\hline${ }^{* *}$ Mean & $<3$ & $<3$ & $<10^{1}$ & Absent \\
\hline F values & Ns & Ns & Ns & Ns \\
\hline$* * *$ Standard & $<3 \mathrm{MPN} \cdot \mathrm{g}^{-1}$ & $<3 \mathrm{MPN} \cdot \mathrm{g}^{-1}$ & $100 \mathrm{CFU} \cdot \mathrm{g}^{-1}$ & Absence/25 g \\
\hline
\end{tabular}

Means did not differ statistically ( $\mathrm{p}>0.05$ ); ${ }^{*}$ linseed oil and palm oil supplement (SLiPa), linseed oil supplement (SLi), palm oil supplement (SPa), soy protein isolate and brewer's yeast supplement (SPiLc), soy protein isolate supplement (SPi), brewer's yeast supplement (SLc); ${ }^{* *}$ Means of all samples (confidence interval $95 \%$ ); ${ }^{* *}$ Standards established by the Brazilian legislation (BRASIL, 2001); Ns= non-significant. 
Barker et al. (1959) challenged the value assigned to the antibiotic acid 10-HDA and reported that the strength of royal jelly upon bacteria and viruses was due to the presence of flavonoids (embodied in the product from the pollen used for its preparation), and propolis (lining the honeycomb that it is in constant contact with the substance during its preparation). Proteins and amino acids also contributed to the antibacterial and fungicide activity because they are widely used by the insect immune system against pathogens (TAKENAKA; ECHIGO, 1980; SAUERWALD et al., 1998).

The results shown in Table 2 may also be associated to the samples short-term storage period (average of three months), which favoured the maintenance of their antimicrobial properties. Chen and Chen (1995) reported that 10-HDA acid is thermo stable, but its bactericidal activity decreases with inappropriate conditions or long storage periods.

Therefore, the presence of active substances (10-HDA acid, amino acids, peptides, flavonoids) in the samples, associated with a low $\mathrm{pH}$, resulted in an improper media for the development of the microorganisms.

\subsection{Physicochemical quality of royal jelly samples}

The physicochemical parameters analyzed are shown in Table 3. The results were compared with the standards established by the Brazilian legislation (BRASIL, 2001).

The results of the physiochemical analysis of royal jelly, although analyzed under rigorous conditions, show slight quantitative discrepancies which can be explained by the variations in the origin of the substance itself, the period of sampling, and, of course, by the error variation which is minimal but existing and inherent to dosing techniques.
It is important to remember that all royal jelly samples were homogenized during collection from each colony for each treatment. Therefore, this table shows data in different way from that shown in Table 1.

There was no significant difference $(p>0.05)$ for the following parameters by ANOVA: $\mathrm{pH}$, moisture, sucrose, protein, ash, and lipids. Similar results were reported by GarciaAmoedo and Almeida-Muradian (2007), who analyzed royal jelly samples from São Paulo city, Brazil.

The values of free acidity and reducing sugar were lower than the limits recommended; however, the Brazilian legislation does not specify which method should be used to analyze royal jelly samples, the direct or indirect titration method.

In the present study, the indirect titration, the method suggested for standardizing samples was used, as recommended by Garcia-Amoedo and Almeida-Muradian (2007). The official method recommended to analyze royal jelly is not accurate when royal jelly is mixed with honey above $30 \%$ in the samples (GARCIA-AMOEDO; ALMEIDA-MURADIAN, 2007).

All free acidity mean values were below the minimum established by the Brazilian legislation (Table 3). This fact demonstrates the importance of reviewing the legislation for royal jelly because the national Africanized honeybee colonies can have different standards from those of European honeybees. Mainly, all procedures used in colony management, grafting larvae, and harvesting and storage of royal jelly were followed. In addition, the nurse honeybees secrete royal jelly, deposit it in the cups with queen larvae, and the royal jelly is then collected, cleaned, and stored and right after that it was analyzed. This means that the royal jelly was fresh, which can explain the low acidity in the samples. Boselli et al. (2003) reported that further investigation on the natural variability of the fresh royal jelly is needed and must be conducted.

Table 3. Physicochemical composition of royal jelly samples (100 g fresh product): F Values, coefficient of variation (CV\%), average values, minimum and maximum and standard established for: $\mathrm{pH}$, acidity $\left(\mathrm{mEq} \cdot \mathrm{kg}^{-1}\right)$, moisture (\%), reducing sugar (\%), sucrose (\%), protein (\%), ash (\%), and lipids (\%).

\begin{tabular}{|c|c|c|c|c|c|c|c|c|}
\hline $\begin{array}{c}\text { Source of } \\
\text { variation }^{*}\end{array}$ & $\mathrm{pH}$ & $\begin{array}{l}\text { Free Acidity } \\
\left(\mathrm{meq} \cdot \mathrm{kg}^{-1}\right)\end{array}$ & $\begin{array}{c}\text { Moisture } \\
(\%)\end{array}$ & $\begin{array}{l}\text { Reducing } \\
\text { sugar (\%) }\end{array}$ & $\begin{array}{c}\text { Sucrose } \\
(\%)\end{array}$ & $\begin{array}{c}\text { Protein } \\
(\%)\end{array}$ & $\begin{array}{l}\text { Ash } \\
(\%) \\
\end{array}$ & $\begin{array}{c}\text { Lipids } \\
(\%)\end{array}$ \\
\hline F Values & 1.48 & 14.26 & 2.42 & 37.39 & 1.06 & 0.88 & 1.89 & 0.92 \\
\hline $\mathrm{P}=$ & 0.2544 & 0.0001 & 0.0815 & 0.0001 & 0.2831 & 0.2598 & 0.1538 & 0.5065 \\
\hline CV (\%) & 0.63 & 1.27 & 0.54 & 2.11 & 2.96 & 2.42 & 23.28 & 19.34 \\
\hline $\mathrm{SLiPa}$ & 3.98 & $20.13 b c$ & 66.69 & $10.54 \mathrm{a}$ & 4.96 & 14.24 & 0.66 & 3.46 \\
\hline $\mathrm{SLi}$ & 3.94 & $20.70 b c$ & 66.93 & $10.42 \mathrm{ab}$ & 5.05 & 14.03 & 0.81 & 4.21 \\
\hline $\mathrm{SPa}$ & 3.99 & $20.00 c$ & 67.01 & $9.97 \mathrm{ab}$ & 4.38 & 14.44 & 0.79 & 3.03 \\
\hline SPiLc & 3.98 & $20.13 b c$ & 66.69 & $9.91 b$ & 4.96 & 14.24 & 0.66 & 3.46 \\
\hline SPi & 3.97 & $21.50 \mathrm{a}$ & 67.08 & $8.40 \mathrm{~d}$ & 3.98 & 14.31 & 1.08 & 3.44 \\
\hline SLc & 3.96 & $20.83 \mathrm{ab}$ & 67.32 & $9.26 \mathrm{c}$ & 4.31 & 14.47 & 0.95 & 3.18 \\
\hline Control & 3.99 & $20.00 c$ & 67.58 & $9.87 b$ & 4.03 & 13.98 & 0.82 & 3.59 \\
\hline $\begin{array}{l}{ }^{* *} \text { Means } \\
(\text { min. and max.) }\end{array}$ & $\begin{array}{c}3.97 \\
(3.92-4.02)\end{array}$ & $\begin{array}{c}20.47 \\
(19.80-21.70)\end{array}$ & $\begin{array}{c}67.04 \\
(66.23-67.81)\end{array}$ & $\begin{array}{c}9.77 \\
(8.32-10.68)\end{array}$ & $\begin{array}{c}4.52 \\
(3.96-5.14)\end{array}$ & $\begin{array}{c}14.24 \\
(13.17-14.76)\end{array}$ & $\begin{array}{c}0.83 \\
(0.39-1.15)\end{array}$ & $\begin{array}{c}3.48 \\
(2.14-5.80)\end{array}$ \\
\hline${ }^{* * *}$ Standard & $3.4-4.5$ & $23.0-53.0$ & $60.0-70.0$ & 10.0 (min.) & 5.0 (max.) & 10.0 (min.) & 1.5 (max.) & 3.0 (min.) \\
\hline
\end{tabular}

Means followed by the same letter, in the columns, did not differ statistically ( $\mathrm{p}>0.05)$; ${ }^{*}$ linseed oil and palm oil supplement (SLiPa), linseed oil supplement (SLi), palm oil supplement $(\mathrm{SPa})$, soy protein isolate and brewer's yeast supplement (SPiLc), soy protein isolate supplement (SPi), brewer's yeast supplement (SLc); ${ }^{* *} \mathrm{Means}$ of all samples (confidence interval 95\%); ${ }^{* * *}$ Standards established by the Brazilian legislation (BRASIL, 2001). 
Marconi et al. (2002) investigated ways to define the freshness of royal jelly using furosine content; Sabatini et al. (2009) used glucose oxidase, and more recently, Kamamura (2011) reported royalactina as responsible for queen differentiation in fresh royal jelly.

The samples had moisture content that ranged from $66.69 \%$ to $67.58 \%$, meeting the requirements of identity and quality of the royal jelly specified by the Brazilian legislation (from $60.00 \%$ to $70.00 \%)$. Lercker et al. (1993) and Krell (1996) reported similar results. The continuous provision of fresh supplies of water by the forager worker honeybees and by the royal jelly natural hygroscopicity maintain the moisture content of the royal jelly.

Moreover, the non-solubility of some compounds can explain the variations in water content (SABATINI et al., 2009).

Only two of the seven mean values of reducing sugar were above the minimum established by the Brazilian legislation, which is $10 \%$. The same explanation given for free acidity should be used for this parameter. Under natural conditions, the hypopharyngeal and mandibular glands secrete royal jelly of nurse worker honeybees from sugars derived from honey, which is manufactured from the nectar. Regarding reducings sugars, the difference found in the royal jelly samples produced with treatments with palm oil supplement, soy protein isolate supplement, brewer's yeast supplement, and between the treatments with linseed oil, palm oil supplement and soy protein isolate plus brewer's yeast supplement (Table 3) must be due to differences in the composition of the sugars, sugar syrup, and nectar present in the supplements, and the environmental conditions in which the samples were produced.

The sucrose mean values were closer to the maximum established by the Brazilian legislation. It is likely that the continuous use of sugar syrup (1:1, sugar-water) as well as the need to secrete royal jelly every three days make nurse worker honeybees regurgitate this sucrose without digestion into the queen cell.

Unlike other honeybee products made by the transformation of compounds collected from plants, the royal jelly composition cannot be directly affected by the types of supplements used (CRANE, 1990) because it is a substance secreted by specific glands, thus, remaining relatively constant when the analysis of different colonies, strains, breeds of the honeybees, production period, and food are compared.

The stability of proteins and lipids of royal jelly during storage at $4{ }^{\circ} \mathrm{C}$ for 10 months did not show significant changes in total lipids and amino acids. However, when stored at room temperature, the lipid content did not change, but the proline and lysine content increased during the first three months, which suggests that if temperature is favorable, it continues to proteolytic activity over time (SABATINI et al., 2009).

The mean values of crude protein and the lipid content ranged from $13.8 \%$ to $14.47 \%$ and $3.03 \%$ to $4.21 \%$, respectively. These values are higher than the minimum established by the Brazilian legislation (Table 3). Since the crude lipid fraction consists of organic acids, it is probable that it is partially responsible for the acidic character of royal jelly (LERCKER et al., 1993).

Ash values ranged from 0.83 to $1.15 \%$, but the treatment with soy protein isolate had the highest ash level. Urano et al. (2006) reported high levels of minerals in this plant, mainly when it originates from high productive varieties.

In the present study, it was found great variations between the royal jelly samples. Other authors also found differences (HAYDAK, 1970; PALMA, 1992; SCHMIDT; BUCHMANN, 1992; LERCKER et al., 1993; SCHMITZOVA et al., 1998; PARFITT, 1999; GARCIA-AMOEDO; ALMEIDA-MURADIAN, 2007) and attributed these differences to the nutritional status of the evaluated colonies, age of mother queens, and the laboratory methods used to analyze their components.

Queiroz, Barbosa and Azevedo (2001) reported that supplementation is good, mainly in the Northeast region of Brazil, for royal jelly production throughout the year, including autumn and winter, periods between flowering, in regions of monoculture such as sugarcane plantation, limited pollen flow or low nutritional pollen quality.

Nevertheless, Toledo et al. (2010) reported that supplementation of Africanized honeybee colonies with commercial product based on $35 \%$ of crude protein did not influence the royal jelly production in the State of Parana, in the south of Brazil.

Another very important factor to be considered is the selection of the Africanized honeybee colonies (MOURO; TOLEDO, 2004; TOLEDO; MOURO, 2005; FAQUINELLO et al., 2011) associated with supplementation as the key to increase royal jelly production, and quality and consequently guarantee more profits to the beekeepers too (SEREIA et al., 2010).

Considering these results, the artificial supplementation did not change the composition of royal jelly produced with the different treatments, thus the provision of supplements to Africanized honeybee colonies subjected to royal jelly production can help and strengthen the technological development of the Brazilian beekeeping industry improving its national market. The values found for royal jelly in the present study are a little different from those established by the Brazilian legislation. This fact shows that it is important to discuss or change the official method to analyze royal jelly.

The characterization of the physicochemical and microbiological parameters is important to standardize fresh, frozen, and lyophilized royal jelly produced by Africanized honeybees.

\section{Acknowledgements}

The authors are grateful to the National Research Council (CNPq, process no. 301943/2005-2 and Araucaria Foundation $37 / 20054025$ for the financial support.

\section{References}

AMERICAN PUBLIC HEALTH ASSOCIATION - APHA. Compendium of methods for the microbiological examination of foods. 3rd ed. Washington: APHA, 1992. 1219 p. 
ASSOCIATION OF OFFICIAL ANALYTICAL CHEMISTRY - AOAC. Official methods of analysis of the Association of Official Analytical Chemists. 14th ed. Arlington: AOAC, 1984. $1141 \mathrm{p}$.

BARKER, S. A. et al. Identification of 10-hydroxy delta 2-decenoic acid in royal jelly. Nature, v. 183, p. 996-997, 1959. PMid:13644271. http://dx.doi.org/10.1038/183996a0

BLUM, M.S.; NOVAK, A. F.; TABER, S. 10-hydroxy delta 2-decenoic acid, an antibiotic found in royal jelly. Science, v. 130, p. 452-453, 1959. PMid:13675771. http://dx.doi.org/10.1126/science.130.3373.452

BOSELLI, E. et al. Determination and changes of free amino acids in royal jelly during storage. Apidologie, v. 34, n. 2, p. 129-137, 2003. http://dx.doi.org/10.1051/apido:2003011

BRASIL. Ministério da Agricultura, Pecuária e Abastecimento. Instrução Normativa n 3, de 19 de janeiro de 2001. Regulamentos técnicos de identidade e qualidade de apitoxina, cera de abelha, geleia real, geleia real liofilizada, pólen apícola, própolis e extrato de própolis. Diário Oficial da República Federativa do Brasil, Brasília, DF, jan. 2001. Seção 1, p. 18-23.

BRASIL. Ministério da Agricultura, Pecuária e Abastecimento. Secretaria de Política Agrícola. Instituto Interamericano de Cooperação para a Agricultura. Cadeia produtiva de flores e mel. Brasília: IICA, MAPA/SPA, 2007. p. 85-134.

CHEN, C.; CHEN, S. Changes in protein components and storage stability of royal jelly under various conditions. Food Chemistry, v. 54, p. 195-200, 1995. http://dx.doi.org/10.1016/03088146(95)00031-D

CRANE, E. The newer hive products: pollen, propolis, royal jelly, bee venom, bee brood. In: CRANE, E. (Ed.). Bees and beekeeping science, practice and world resources. London: Comstock Publishing Associates, 1990. p. 452-465.

DOOLITTLE, G. M. Doolittle's queen rearing methods. American Bee Journal, v. 39, p. 435-436, 1899.

FAQUINELLO, P. et al. Parameters of royal jelly production in Africanized honeybees. Sociobiology, v. 57, n. 3, p. 495-509, 2011.

FONTANA, R. et al. Jelleines: a family of antimicrobial peptides from the Royal Jelly of honeybees (Apis mellifera). Peptides, v. 25, n. 6, p. 919-928, 2004. PMid:15203237. http://dx.doi.org/10.1016/j. peptides.2004.03.016

GARCIA-AMOEDO, L. H.; ALMEIDA-MURADIAN, L. B. Physicochemical composition of pure and adulterated royal jelly. Química Nova, v. 30, n. 2, p. 257-259, 2007. http://dx.doi.org/10.1590/S010040422007000200002

HAYDAK, M. H. Vitamin content of royal jelly from honey bee colonies fed normal diet and from those fed pollen substitutes. Annals of the Entomological Society of America, v. 53, n. 5, p. 695, 1960.

HAYDAK, M. H. Honey bee nutrition. Annual Review of Entomology, v. 15, p. 143-156, 1970. http://dx.doi.org/10.1146/annurev. en.15.010170.001043

KAMAMURA, M. Royalactina induces queen differentiation in honeybees. Nature, v. 473, p. 478-483, 2011. PMid:21516106. http:// dx.doi.org/10.1038/nature10093

KRELL, R. Value added products from beekeeping. Rome: Food and Agriculture Organization, 1996. p. 87-113.

LAVIE, P. Proprie te's antibacteriennes et action physiologique des produits de Ia ruche et des abeilles. Chauvin, v. 3, p. 1-115, 1968.

LERCKER, G. et al. Caratterizzazione dei principali costituenti della gelatina reale. Apicoltura, v. 8, p. 27-37, 1993.

MARCONI, E. et al. Furosine: a suitable marker for assessing the freshness of royal jelly. Journal of Agricultural and Food
Chemistry, v. 50, p. 2825-2829, 2002. PMid:11982406. http://dx.doi. org/10.1021/jf0114987

MOURO, G. F.; TOLEDO, V. A. A. Evaluation of Apis mellifera Carniolan and Africanized honey bees in royal jelly production. Brazilian Archives of Biology and Technology, v. 47, p. 469-476, 2004. http:// dx.doi.org/10.1590/S1516-89132004000300018

PALMA, M. S. Composition of freshly harvested Brazilian royal jelly: identification of carbohydrates from the sugar fraction. Journal of Apicultural Research, v. 31, n. 1, p. 42-44, 1992.

PARFITT, K. Martindale. 32nd ed. London: Pharmaceutical Press, 1999. $1626 \mathrm{p}$.

QUEIROZ, M. L.; BARBOSA, S. B. P.; AZEVEDO, M. Produção de geleia real e desenvolvimento de abelhas Apis mellifera, na região semi-árida de Pernambuco. Revista Brasileira de Zootecnia, v. 30, n. 2, p. 449-453, 2001. http://dx.doi.org/10.1590/S151635982001000200022

SABATINI, A. G. et al. Quality and standardisation of royal jelly. Journal of Api Product and ApiMedical Science, v. 1, n. 1, p. 1621, 2009. http://dx.doi.org/10.3896/IBRA.4.01.1.04

SAUERWALD, N. et al. Combined antibacterial and antifungal properties of water soluble fractions of royal jelly. Advances in Food Science, v. 20, n. 1-2, p. 46-52, 1998.

SCHMIDT, J. O.; BUCHMANN, S. L. Other products of the hive. In: GRAHAM, J. M. (Ed.). The hive and the honeybee. Hamilton: Dadant and Sons, 1992. p. 927-988.

SCHMITZOVA, J. et al. A family of major royal jelly proteins of the honeybee Apis mellifera L. Cellular and Molecular Life Sciences, v. 4, n. 9, p. 1020-1030, 1998. http://dx.doi.org/10.1007/ s000180050229

SEREIA, M. J. et al. Viabilidade financeira da produção de geleia real com abelhas africanizadas suplementadas com diferentes nutrientes. Acta Scientiarum - Animal Sciences, v. 32, n. 4, p. 467-474, 2010. http://dx.doi.org/10.4025/actascianimsci.v32i4.7895

SOMOGY, M. A new reagent for determination of sugars. The Journal of Biological Chemistry, v. 160, p. 61-68, 1945.

STATISTICAL ANALISYS SYSTEM INSTITUTE - SAS. SAS user's guide version 8. 13th ed. Cary: SAS Institute, 2007.

TAKENAKA, T.; ECHIGO, T. General chemical composition of the royal jelly. Bulletin of the Faculty of Agriculture, v. 20, p. 7178, 1980 .

TOLEDO, V. A. A.; MOURO, G. F. Produção de geleia real com abelhas africanizadas selecionadas cárnicas e híbridas. Revista Brasileira de Zootecnia, v. 34, p. 2085-2092, 2005. http://dx.doi.org/10.1590/ S1516-35982005000600034

TOLEDO, V. A. A. et al. Produção de geleia real em colônias de abelhas africanizadas considerando diferentes suplementos proteicos e a influência de fatores ambientais. Acta Scientiarum Animal Sciences, v. 32, n. 1, p. 93-100, 2010. http://dx.doi.org/10.4025/ actascianimsci.v32i1.6836

URANO, E. O. M. et al. Avaliação do estado nutricional da soja. Pesquisa Agropecuária Brasileira, v. 41, n. 9, p. 1421-1428, 2006. http://dx.doi.org/10.1590/S0100-204X2006000900011

VIUDA-MARTOS, M. et al. Functional properties of honey, propolis, and royal jelly. Journal of Food Science, v. 73, n. 9, p. 117-124. 2008. PMid:19021816. http://dx.doi.org/10.1111/j.17503841.2008.00966.x

WILLSON, R. B. Royal jelly: a review. American Bee Journal, v. 95, p. 15-21, 1955.

WINSTON, M. L. The biology of the honey bee. Massachusetts: Harvard University Press, 1987. 281 p.

YATSUNAMI, K.; ECHIGO, T. Antibacterial activity of royal jelly. Bulletin of the Faculty of Agriculture, v. 25, p. 13-22, 1985. 